\title{
Matéria vertente: “Grande Sertão Veredas" de Guimarães Rosa e o Rio São Francisco
}

Adélia Bezerra de Meneses

A grande metáfora de Grande Sertão Veredas, de Guimarães Rosa, junto com a do Sertão, é o Rio. Inclusive, entranhadamente ligadas. Sabemos o quanto o rio, além de realidade geográfica, é uma realidade mítica e mágica.

Basicamente, como se estrutura o romance? Trata-se de uma narrativa apresentada como uma longa conversa do ex-jagunço Riobaldo, um sertanejo que detém o poder da fala e que conta a sua vida a um doutor da cidade (que nunca comparece), e esse narrar se configura como uma busca desesperada de sentido para o vivido.

É assim que o protagonista, Riobaldo, propõe o assunto da conversa a seu interlocutor:

\footnotetext{
Vou the falar. Lhe falo do sertão. Do que não sei. Um grande sertão! Não sei.

Ninguém ainda não sabe. Só umas rarísimas pessoas - e só essas poucas veredas, veredazinhas. ${ }^{1}$ (p. 79) ${ }^{2}$
}

E um pouco mais adiante, explicita: o sertão é o dentro da gente. Esses textos, dentre muitos outros que se poderiam pinçar ao longo de GSV equiparam o sertão ao "dentro da gente". O grande sertão da alma de um homem: aquilo que ele não sabe, mas de que tentará se acercar, "organizando" sua experiência, nesse encontro a dois, nessa relação em que um ser humano escuta o outro e, ao escutá-lo, ao acolher sua fala, propõe um receptáculo a esse jorro verbal que caracteriza o protagonista, e o ajuda a organizar-se, o estrutura. ${ }^{3}$ É como se a escuta do interlocutor fornecesse um continente a essa "matéria vertente" que jorra, infinita e 
desorganizada, e lhe dá um curso, margens, delimitações, um leito no qual correr.

As alusões aos protagonistas aferidos aos rios pontilham o texto; mas a "matéria vertente" é a narrativa da vida, sempre.

Mas o senhor sério tenciona devassar a raso este mar de territórios, para sortimen-

to de conferir o que existe? Tem seus motivos.,

diz Riobaldo ao interlocutor. E em seguida:

Mas então, para uma safra razoável de bizarrices, reconselho de o senhor entestar viagem mais dilatada. (p. 23)

A insinuada ambigüidade entre a escuta das bizarrices e uma "viagem mais dilatada" se aguça:

Lhe mostrar os altos claros das Almas: rio despenha de lá, numa afã, de espuma próspero, gruge; cada cachoeira, só tombos. O cio da tigre preta na Serra do Tatu

- já ouviu o senhor gargaragem de onça? [...] Quem me ensinou a apreciar essas belezas sem dono foi Diadorim. (p. 23)

Aí estaria o intento, o objetivo da conversa do Riobaldo, endereçada ao senhor doutor culto da cidade: mostrar-lhe os altos claros das $\mathrm{Al}$ mas - e o rio que despenha de lá. Os planos geográfico e psicológico se sobreporão: "mostrar os altos claros das almas" talvez seja uma explanação do termo "Psico-análise", se estivermos atentos à etimologia de psique = alma e à "Aufklärung", ao percurso de "esclarecimento" que o processo analítico propicia. (Num parênteses: não se pode deixar de enxergar no "cio da onça preta" esse núcleo pulsional do humano, ser sexualizado. A isso retornarei mais adiante.) O pedido de Riobaldo ao doutor da cidade é uma demanda de autoconhecimento: 
eu queria decifrar as coisas que são importantes. Queria entender do medo e da coragem, e da gã que empurra a gente para fazer tantos atos, dar corpo ao suceder.

O que induz a gente para as más ações estranhas. (p. 79)

O Rio, o rio que despenha, é assim uma metáfora fundamental do romance. Vamo-nos deter nessa figura de linguagem, a metáfora, cujo fundamento é uma relação analógica ${ }^{4}$.

O filósofo Giambatista Vico, para quem a metáfora é um pequeno mito, no seu extraordinário Scienæa Nuova, em pleno século XVII, defende a idéia de que a poesia precede a prosa, de que os homens primitivamente falavam por poesia, e só posteriormente a linguagem racional da prosa se instaura. Os homens, por necessidade de expressão, falariam por imagens. Disso já se infere que a fala poética não é enfeite, adorno, um refinamento tardio, mas algo de essencial, de vitalmente necessário. A metáfora aparece como fruto de uma necessidade ineludível de expressão. "A mente humana", diz Vico, "inclina-se, muito naturalmente, mediante os sentidos, a fazer-se visível no corpo e, com muita dificuldade, por meio da reflexão, entender-se a si própria". ${ }^{5}$ Isso fornece o princípio segundo o qual os homens falariam por imagens, tendo por base a si próprios - seu próprio corpo e suas paixões. Textualmente: “os vocábulos são transpostos dos corpos e das propriedades dos corpos para a significação das coisas da mente e do espírito."

Mostrando o caráter fundamentalmente orgânico da formação das imagens, e a importância do corpo nesse processo, Vico aponta que, nas várias línguas, a maior parte das expressões das coisas inanimadas é efetuada "mediante translações do corpo humano e de suas partes, assim como dos sentidos humanos e das humanas paixões": por exemplo, cabeça é utilizada por princípio, ou por cimo; fronte, costas, por adiante e atrás; boca, por abertura; lábios, por bordas; fala-se em garganta de terra, língua do mar, braço do rio, seio do mar (por golfo), carne das frutas. $\mathrm{E}$ ainda: sopra o vento, murmura a onda, ri o céu, geme um objeto de grande peso. Assim, diz o filósofo napolitano, “o homem se faz regra do 
universo" e "a partir de si próprio erige um mundo inteiro". Toca-se aqui no cerne da questão da sensorialidade que anima o fazer poético. A metáfora, para Vico, dá "sentimento e paixão" às coisas todas. É todo o mundo dos afetos que se vê convocado.

Vico estabelece então no movimento de nomear utilizando a palavra (esse processo fundamental de simbolização), como operação básica, a analogia. E aponta o mecanismo segundo o qual o ser humano projeta o próprio corpo na realidade circundante, e através dele nomeia a natureza.

Pois bem, é tal processo que a gente vê em ação no caso dessa ligação de comunhão profunda do homem com o Rio - sobretudo de um homem de uma região em que esse rio é fonte de Vida.

Para o filósofo napolitano, na necessidade inelutável de expressão, o homem busca no seu próprio corpo a maneira de nomear as coisas. Dito em outras palavras, os homens emprestam às coisas a sua própria natureza, entendem o mundo a partir de si próprios: por exemplo, admirando os efeitos do ímã sobre o ferro, dizem que o ímã estaria enamorado do ferro, "convertendo, por tal modo, toda a natureza em um vasto corpo animado, que sente paixões e afetos...".

Em Grande Sertão Veredas, cujo título condensa exatamente as duas metáforas fundamentais do romance: sertão e rios, é exatamente esse "sentimento e paixão" que se vê na relação de correspondência dos protagonistas com o rio.

Nunca é demais repetir que a poesia depende de uma intensidade privilegiada de sentidos, e de riqueza afetiva; depende de uma aguçada e sensível percepção das coisas e da vida, e de capacidade de comunhão profunda e compreensiva com a realidade. $\mathrm{O}$ poeta é um ser atento às analogias e correspondências - e sabemos em que medida o senso das "Correspondances" "é fundamental no processo poético. Por outro lado, ele tem o poder (inquietante!) de lidar com as palavras, explorando-lhes os efeitos sensoriais e plásticos, deles extraindo tudo o que poderiam 
render, na força plástica, visual, gestual, sensorial da linguagem. Para Hegel, poesia é o "luzir sensível da idéia".

Mas esse processo apontado por Vico, em que na sensorialidade do fazer poético se vê a projeção do ser humano - a projeção do corpo humano e "das humanas paixões" sobre a paisagem - dá-se em Grande Sertão Veredas sobretudo em relação ao rio, mas não exclusivamente. $\mathrm{O}$ amor de Riobaldo por Diadorim faz, metonimicamente, com que a natureza toda seja vista como impregnada daquilo era a característica fundamental do seu amigo: "os olhos aos grandes, verdes".?

Assim, além dos rios verdes, ("Saí, vim destes meus gerais: voltei com Diadorim. Não voltei? Travessias... Diadorim, os rios verdes" - p. 235), o buriti de palmas verdes é metonímia de Diadorim ("ah, meus buritizais levados de verde,"); qualquer palmeira pode indiciar Diadorim ("namorei uma palmeira"); também o vento: "o vento é verde"; até o mar: "Morreu o mar, que foi" - diz ele, comentando a morte de Diadorim. Há mesmo uma passagem em que Riobaldo resume tudo isso numa frase: "Diadorim me pôs o rastro dele para sempre em todas essas quisquilhas da natureza. ${ }^{10}$ (p. 25).

E ainda: "Mas eu gostava de Diadorim para poder saber que esses gerais são formosos" (p. 46).

No entanto, apesar de comparecerem outros elementos da Natureza nessa projeção, é o Rio o elemento que condensa metaforicamente, e que se projeta, metonimicamente, nas personagens principais, Riobaldo e Diadorim.

A vida das personagens, o "verter da sua presença", é aferida aos rios ("Dois rios diferentes, era o que nós dois atravessamos?" - p. 268 pergunta-se Riobaldo); assim como a narrativa de suas vidas, o poderoso jorro verbal, "matéria vertente" que é o relato do protagonista narrador diante do seu interlocutor silencioso.

Cavalcanti Proença, no seu belo estudo "Trilhas no Grande Sertão" no topos "O Plano Mítico" mostra que as próprias "fases da vida dos protagonistas encontram reflexo no rio": assim a cólera pela morte 
de Joca Ramiro é uma enchente, diz ele; a morte de Medeiro Vaz também acontece em meio a uma chuva pesada. Mas sobretudo Cavalcanti Proença atribui ao Urucuia, dentre os vários rios que alimentam as Veredas do Grande Sertão, o apanágio de representar o jagunço Riobaldo, que com ele se identificaria ${ }^{11}$ - o que é, de uma certa maneira, discutível, como se verá a seguir. Apesar de fazer várias declarações de amor ao Urucuia ("Meu rio de amor é o Urucuia") - sendo que também é esse o rio que por vezes representa Otacília, ("Otacília sendo forte como a paz feito aqueles largos remansos do Urucuia, mas que é rio de braveza”), parece ser realmente o Rio São Francisco que figura com mais intensidade a relação de Riobaldo e Diadorim , e sua recíproca paixão.

Em todo o caso, se o sertão é o mundo, o rio são os homens. Mas aqui nesse mundo de imensidão de rios que cumprem seu destino geográfico e poético, um é o Rio - no romance, somos advertidos: "Agora, por aqui, o senhor já viu: rio é só o São Francisco, o Rio do Chico. O resto pequeno é vereda. E algum ribeirão."

Assim, a minha proposta básica é aferir essa "matéria vertente" que é o discurso do protagonista, ao Rio São Francisco, a um só tempo mítico e geográfico, realidade mágica e emblema paisagístico, elemento estruturador do enredo e do espaço narrativo e - enquanto "encruzilhada de várias cadeias associativas" - uma das metáforas fundamentais do romance. Dada sua importância fulcral como "rio da unidade nacional o Rio São Francisco atravessa vários estados brasileiros, garantindo-lhes a possibilidade de sobreviver à seca, ${ }^{12}$ era de se esperar que marcasse profundamente, assim como outro rio emblemático, que é o Amazonas, o imaginário literário brasileiro.

O que seria o específico de minha proposta é que o São Francisco aparece em Grande Sertão Veredas não como elemento paisagístico, delimitador de territórios, ou engendrador de lendas, ou mesmo como ilustres avatares, antropomorfizado; nem apenas como elemento estruturador do enredo, como apontou Antonio Candido, que, atentando para a sua função no livro, mostra que o Rio São Francisco divide o mundo do 
sertão em duas partes: "o lado direito e o lado esquerdo, carregados do sentido mágico-simbólico que essa divisão representa para a mentalidade primitiva. O direito é o fasto; nefasto o esquerdo" ${ }^{\text {"13 }}$. Mas o mais importante é que o rio é suporte de uma projeção dos protagonistas, Riobaldo e Diadorim:

Diadorim, esse, o senhor sabe como um rio é bravo? É, toda a vida, de longe a longe, rolando essas braças águas, de outra parte, de fugida, no sertão. (p. 323)

Apesar de toda a imensa rede associativa tecida pelo rio em Grande Sertão Veredas, nesse romance, afunilando-se o espectro, Rio (sobretudo o Rio do Chico, mas também o Urucuia), metafórica e metonimicamente figurarão a paixão, o Desejo.

Seria o caso de a gente se deter (mesmo que minimamente) no riquíssimo simbolismo das águas, a que a maior parte das civilizações atribui um poder cósmico mágico, de fonte de vida, simbolismo universal de fecundação, de fertilização e de poder regenerador, origem da Criação. $\mathrm{Na}$ civilização judaico-cristã, a água fonte de vida está presente do Gênesis ao Apocalipse. ${ }^{14}$

Mas se a água é fonte de vida, ela também pode ser fonte de morte, como nos diz a imagem universal do Dilúvio. Ambíguas e contraditórias como o ser humano, as águas de um rio são criadoras e destruidoras:

A vida é muito discordada. Tem partes. Tem artes. Tem as neblinas de Siruiz:

Tem as caras todas do Cão, e as vertentes do viver. (p. 381)

Como a paixão:

Ah, meu senhor! Como se o obedecer do amor não fosse sempre ao contrário. O senhor vê, nos gerais longe: nuns lugares, encostando o ouvido no chão, se escuta barulho de fortes águas, que vão rolando debaixo da terra. O senhor dorme sobre um rio... (p. 222) 
Essas "fortes águas" subterrâneas, força vital mal represada, e que aflora insopitável com toda a violência das pulsões, com todo seu poder seminal - que figuração mais expressiva poderia se pensar para a libido ${ }^{15}$, força irrefreável?

Nesse enquadramento é que se pode interpretar a emblemática travessia do Rio São Francisco, no encontro dos dois protagonistas, adolescentes, Riobaldo e o "Menino", Diadorim. É um encontro que se dá no Porto do rio chamado "de Janeiro", que deságua no São Francisco. E a melhor maneira de se atravessar para a sua outra margem, nessa região, é exatamente nesse lugar, em que o de-Janeiro esbarra no São Francisco:

quem quer bandear a cômodo o São Francisco, também principia ali a viagem.

(p. 79)

Passagem absolutamente emblemática, travessia iniciática, é bom que nos detenhamos nela:

\footnotetext{
Mas com pouco, chegávamos no do-Chico. O senhor surja: é de repentemente aque-

la terrivel água de largura: imensidade. Medo maior que se tem, é de vir canoando num ribeirãozinho, e dar, sem espera, no corpo dum rio grande. Até pelo mudar.

A feiúra com que o São Francisco puxa, se moendo todo barrento vermelho, recebe para si o de-Janeiro, quase só um rego verde só. - "Daqui vamos voltar,?”- eu pedi, ansiado. O menino não me olhou - porque já tinha estado me olhando,como estava. - "Para que?"- ele simples perguntiou, em descanso de paz [...].
}

Mas mesmo diante do medo do amigo recente, e do seu grito, o Menino "sério, naquela sua formosa simpatia, deu ordem ao canoeiro, com uma palavra só, firme mas sem vexame: - 'Atravessa!' O canoeiro obedeceu." [...].

Trata-se de uma passagem que deverá ser posta em paralelismo com outra, altamente simbólica, do romance, que é a travessia do Liso do Sussuarão, deserto-símbolo, tentada pelo bando dos jagunços, uma 
primeira vez, liderada por Medeiro Vaz, e fracassada; mas que depois, sob o comando de Riobaldo, por desejo de Diadorim (que assim via como viabilizar a vingança da morte do pai, Joca Ramiro), será realizada com êxito. Quer se trata d "aquela terrível água de largura: imensidade" ou de um lugar em que "Água, não há”, a ordem é uma só: “Atravessa”!

Sabemos o quanto a travessia de um rio é importante, simbolicamente, em tradições culturais, de algumas civilizações. Na China antiga, por exemplo, era costume os jovens casais a realizarem, no equinócio da primavera, como um rito de travessia (travessia do ano, das estações, do yin ao yang, purificação preparatória à fecundidade). ${ }^{16}$

Mas continuemos a iniciática travessia dos dois meninos, a primeira e inaugural. Diz Riobaldo:

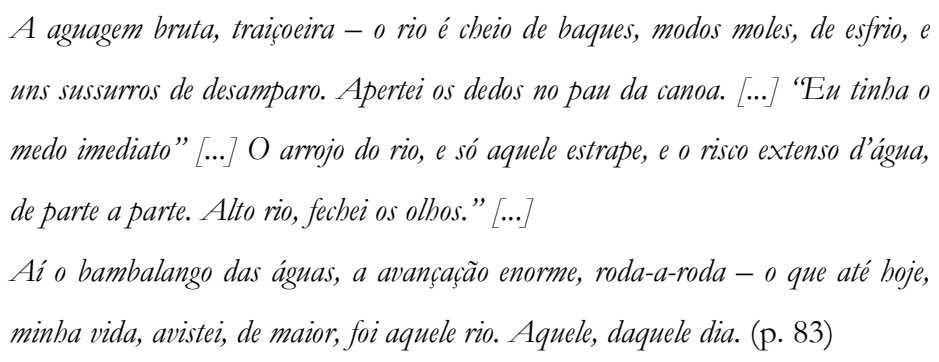

E depois de uma conversa sobre a coragem - "Carece de ter muita coragem..." - e do canto do canoeiro - "Meu Rio de São Francisco, nessa maior turvação: vim te dar um gole d'água, mas pedir tua benção... - eles chegam: "Aí o desejado, arribamos na outra beira, a de lá." (p. 84)

Passagem emblemática, travessia iniciática, a partir daquele dia tudo muda na vida de Riobaldo: ele nota "uma transformação, pesável." E é por isso que dirá, de uma maneira definitiva: "O São Francisco partiu minha vida em duas partes".

Há todo uma subcorrente erótica naquelas fortes imagens, que evocam "o corpo de um grande rio": “o bambalango das águas, a avan- 
çação enorme, roda-a-roda."; "Uma aguagem bruta, traiçoeira - o rio é cheio de baques, modos moles, de esfrio, e uns sussurros de desamparo"; do rio túrgido das cheias, ao poderoso fluxo que ele representa (bem como o poderoso jorro verbal da narrativa, que tem no rio o seu símile,) as imagens são fortemente sexualizadas:

Eu queria a muita movimentação, horas novas. Como os rios não dormem. O rio não quer ir a nenhuma parte, ele que é chegar a ser mais grosso, mais fundo. (p. 329)

E Diadorim parava calado, próximo de mim, e eu concebi o verter da presença dele, quando os nossos dois pensamentos se encontravam. Que nem um amor no aoescuro, um carinho que se ameaçava.

Ou a canção do Siruiz, cujas estrofes pontilham o romance, e das quais ressalto:
Urucuia - rio bravo
Cantado à minha feição
É o dižer das águas claras
Que turvam na perdição (p. 241) $)^{17}$

E o refrão, na sua ambigüidade erótico-bélica, sexualizada:

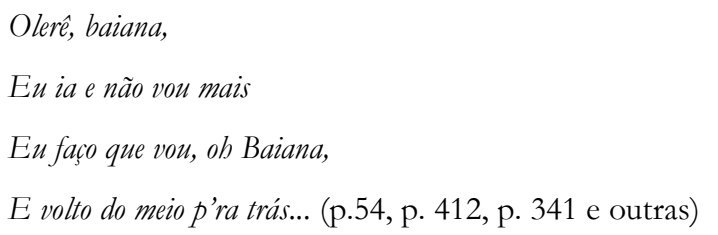

Até acabar, precedendo de poucas linhas a última palavra - "Travessia" na metáfora inapelavelmente fálica com que se fecha o romance: 
O rio de São Francisco que, de tão grande se comparece - parece é um pau grosso,

em pé, enorme... (p. 460)

É extremamente significativo que num outro momento forte do romance, que é o momento do pacto das Veredas Mortas, quando, convocado , o Diabo não surge - mas o pacto fica selado (fica? Será essa a dúvida que atormentará o protagonista até o fim de seus dias) -, uma alusão mais propriamente libidinal se patenteie. Depois de invocar, de esperar, e de convocar o Diabo, que não aparece, Riobaldo reitera:

\footnotetext{
- Ei, Lúcifer! Satanás, dos meus Infernos!

Voz minha se estragasse, em mim tudo era cordas e cobras. E foi aí. Foi. Ele não existe, e não apareceu nem respondeu - que é um falso imaginado. Mas eu supri que ele tinha me ouvido. Me ouviu, a conforme a ciência da noite e o envir dos espaços, que medeia. Como que adquirisse minhas palavras todas; fechou o arrôcho do assunto. Ao que eu recebi de volta um adejo, um gozo de agarro, dai umas tranqüilidades - de pancada. Lembrei dum rio que viesse adentro a casa de men pai. (p. 319)
}

Nesse instante, em que há "arrocho", "adejo", um "gozo de agarro", e "daí umas tranqüilidades" - com todas as alusões orgásticas que daí possam advir -, Riobaldo se lembra "dum rio que viesse adentro a casa de (seu) pai" - numa enevoada alusão à cena primordial parental (em que mãe = "casa", assim como pai $=$ rio - provavelmente como o São Francisco, naquela figuração de que ele se reveste ao fim de Grande Sertão Veredas, e que referi mais acima: "um pau grosso, em pé, enorme"....

E finalmente, como não podia deixar de ser, cabem algumas observações a respeito da presença do rio no nome dos protagonistas. ("Que é que é um nome? Nome não dá; nome recebe" (p. 121). reflete Riobaldo. Muito já se falou dos significados condensados embutidos no nome de Diadorim (que, enquanto corruptela de "Deodorina", é "dom 
de Deus", e é dor, e é "através da dor", e é "diá" = diabo, mas também "dia"; e ainda, na parte final desse nome, pode-se vislumbrar dia de Nossa Senhora da $\mathrm{Abadia}^{18}$ ); também muito já se falou a respeito da significação mais evidente de Rio baldo, que carrega em seu próprio nome, evidentemente, Rio, mas também o sema da falta, da inutilidade. Baldo, de origem árabe (de batil = inútil) e que vive nos advérbios "embalde" e na locução adverbial "debalde" (= em vão), originou o adjetivo "baldo", e "baldio" (conhecido na expressão "terreno baldio"= não cultivado, inculto, sem proveito, inútil); e o verbo "baldar" = tornar inútil (como em "baldados esforços").

Mas como em Guimarães Rosa nada é unívoco, como Deus é o Diabo, como Diadorim é dom de Deus e é Diá, também baldo tem outra acepção dicionarizada contraditória: barragem ou parede para represar... as águas de um açude. Daí a palavra "balde" = recipiente. Aqui também se verificaria uma relação, no nível dos nomes, entre os dois protagonistas: Riobaldo, que carrega o sema da falha, da inutilidade, do vazio, Riobaldo é aquele que... represa águas. Da correnteza de um rio. Explico: há um momento no romance em que Diadorim comenta a similaridade sonora entre os nomes "Riobaldo" e "Reinaldo". Ora, em Reinaldo, a primeira parte do nome (a que não rima com Riobaldo), rei, remete ao verbo grego réo = correr: (lembremo-nos do "panta rei" = tudo corre, de Heráclito). E como já disse, em Guimarães Rosa nada é por acaso, é significativo que na passagem em que Diadorim lhe revela que não se chama Reinaldo, mas sim Diadorim, logo em seguida Riobaldo declare: "Esses rios têm de correr bem!” (p. 121) - o que, menos do que comentário ao nome recém-revelado de Diadorim, refere-se a Reinaldo (em que rei $=$ corre). Na realidade, se se for desprezar o aspecto mais propriamente formal (concordância de sons, rima), pode-se, no nível etimológico, verificar um outro profundo acordo entre esses dois nomes, entre essas duas personagens: se Riobaldo é o rio "vão", também pode ser aquele que represa, como açude... as águas desse rio, que "corre bem". 
É verdade: segundo o compadre Quemelém, a realidade é contraditória: "comprar ou vender, às vezese, são as ações que são as quase iguais..." (p. 460). Pois o romance todo versa sobre a ambigüidade, a fundamental contradição que habita o sertão e que nos habita, que marca a vida das pessoas e que impregna, como na canção de Siruiz, os versos que Riobaldo "tira" antes da batalha final contra o Hermógenes, o pactário:

Remansos de Rio largo,

Deus ou demo, no sertão. (p. 424)

\section{Notas}

1 Veredas, no seu sentido dicionarizado, registra, além do mais conhecido (no Sul do Brasil) que é "caminho", também aquele que diz respeito à região do sertão de G. Rosa (Minas Gerais): “cabeceira e curso d'água orlados de buritis, especialmente na zona sãofranciscana" (Novo Dicionário Aurélio).

2 As páginas das citações aqui referidas são da $8^{\mathrm{a}}$ edição de Grande Sertão Veredas (Rio de Janeiro: José Olympio Editora, 1972).

3 Cf. Adélia Bezerra de Meneses: "Grande Sertão Veredas e a Psicanálise de Riobaldo". Texto a ser publicado na revista Scripta (Número especial sobre Guimarães Rosa), org. Lélia Parrreira Duarte, CESPUC-MG, no $2^{\circ}$ semestre de 2002.

4 Embora nem todos os símbolos operem por analogia, como se pode verificar na Matemática ou na Lingüística; mesmo na Psicanálise, o próprio Freud, ao falar do simbolismo nos sonhos, refere-se à alusão: assim, a vestimenta, em sonhos, pode dizer respeito ao seu contrário, a nudez. Mas, em se tratando especificamente da Literatura, creio que se pode dizer, com Fernando Pessoa, que "Tudo é simbolo e analogia".

5 Vico, Princípios de uma Ciência Nova, trad. Antonio Lázaro de Almeida Prado. S. Paulo: Abril Cultural, $2^{\mathrm{a}}$ ed., 1979, p. 48.

6 Idem, ibidem.

7 Vico, op. cit. 
8 Cf. Baudelaire: "La Nature est un temple où des vivants piliers/ Laissent parfois sortir des vivantes paroles. L'Homme y passe à travers une forêt de symboles/ Qui le regardent avec des yeux familiers".

9 Cf. na tradição da canção brasileira, a Asa Branca: "quando o verde dos teus olhos/ se espraiar na plantação/ eu voltarei, viu, não chores não, viu,/ eu voltarei, viu, meu coração” (de Luís Gonzaga).

E como "coração mistura amores", Riobaldo sobreporá as imagens de Otacília e Diadorim: ele se casa com Otacília "quando deu o verde nos campos" (p. 45). E são saudades de Otacília que o fazem evocar a estrofezinha: "Buriti, minha palmeira,/ lá na vereda de lá:/ casinha da banda esquerda,/ olhos de onda do mar...” (p. 42) No entanto, logo em seguida a esses versos, acrescentará: "Mas os olhos verdes sendo os de Diadorim" (p. 42).

10 Como João da Cruz, no Cantico Espiritual, falando que o amado revestiu de formosura a Natureza:

"Mil gracias derramando,/ pasó por estos sotos com presura,/ y yéndolos mirando,/ con sola sua figura/ vestidos los dejó de hermosura".

11 Cf. Cavalcanti Proença: “Trilhas no Grande Sertão”, In Augusto dos Anjos e Outros Ensaios. Rio de Janeiro: José Olympio, 1959, pp. 151-241.

12 Apesar da aflitiva situação atual, em que a ação anti-ecológica pesada o compromete, chegando a diminuir significativamente suas grandes águas.

13 Antonio Candido, "O Homem dos Avessos". Tese e Antítese, S. Paulo: Cia. Editora Nacional, $2^{\mathrm{a}}$ ed., 1971.

14 Desde “O espírito de Deus pairava sobre as águas”(Gen. I, 2), no caos indiferenciado que precede a Criação, até o novo radical instaurado no Apocalipse: "O Cordeiro os conduzirá às fontes de água da vida” (Apoc. 7, 17).

15 Cf. a representação freudiana para a libido, como corrente líquida.

16 Cf. Jean Chevalier/Alain Gheerbrant: Dicionário de Símbolos (Trad.) Rio de Janeiro: José Olympio, 1977, 11 a ed.

17 E que tem a mesma toada desse "canto de cantiga" que Riobaldo "tira", antes da batalha final com o Hermógenes: 
Remanso de rio largo...

Deus ou demo, no sertão

18 Como, aliás, sugere o próprio Riobaldo: "Diadorim, nas asas do instante, na pessoa dele vi foi a imagem tão formosa de Nossa Senhora da Abadia". 